

Й. В. Андрашек', В. М. Максимів ${ }^{1}$, о. М. Петросюк ${ }^{2}$

${ }^{1}$ Національний лісотехнічний університет України, м. Львів, Україна

${ }^{2}$ ТзОВ "Анерухомість", смт Великий Любінь, Украӥна

\title{
ЕКСПЕРИМЕНТАЛЬНІ ДОСЛІДЖЕННЯ КІНЦЕВОЇ ВОЛОГОСТІ ТЕРМІЧНО МОДИФІКОВАНОЇ ДЕРЕВИНИ ЯСЕНЯ
}

Дослідження проведено на базі приватного підприємства "Long life wood" у термокамері власного виготовлення. За результатами експериментальних досліджень встановлено, що без кондиціювання кінцева вологість термічно обробленої деревини ясеня становить 0,6-1,4 \%, що недопустимо, оскільки кінцева вологість повинна мати значення на рівні 4-5 \%. Для вирішення цієї проблеми запропоновано режими кондиціювання (зволоження), запровадження яких дасть змогу підвищити кінцеву вологість термічно модифікованої деревини ясеня до необхідного рівня $\mathrm{i}$, як наслідок, забезпечить стабільність форми і розмірів виробів у процесі експлуатації. Використовуючи явище розрідження від різкого зниження температури, зволоження відбувається завдяки всмоктуванню конденсату, що утворився на початкових фазах термооброблення і накопичився у спеціальних ємкостях через спеціальні зволожувальні труби. Надалі поданий конденсат миттєво перетворюється в пару, оскільки температура всередині термокамери істотно вища $100^{\circ} \mathrm{C}$ і створює практично стан повного насичення водяною парою в термокамері. За результатами досліджень запропоновано рекомендації стосовно тривалості кондиціювання термічно модифікованої деревини ясеня залежно від температури оброблення і товщини матеріалу.

Ключові слова: рівноважна вологість; термічно модифікована деревина; вакуум; термічно модифікований ясень; термогравіметричний метод; ваговий метод.

Вступ. Ідея створення термодеревини полягає у використанні безперечних переваг звичайної деревини як будівельно-оздоблювального матеріалу. До безумовних переваг деревини належать: доступність за ціною, екологічність, легкість оброблення, широкий спектр використання і практично невичерпний запас (відновлюваність ресурсів).

Незважаючи на те, що на науково-дослідному рівні технологія виготовлення термодеревини як така, що давала б змогу отримати екологічно чистий продукт із задовільними фізико-механічними властивостями та зовнішнім виглядом, розробляється впродовж тривалого часу, під час застосування ii на практиці виникають проблеми, що обмежують можливість отримання кінцевого якісного продукту (Andrashek, et al., 2013). Однією 3 них є проблема досягнення необхідної кінцевої вологості термічно обробленої деревини. Це пов'язано з тим, що рівноважна вологість термічно модифікованої деревини в 2-3 рази нижча від натуральної деревини (Wahl, 2008) i, як наслідок, кінцева вологість ТМД у виробах, що експлуатуються в зовнішньому середовищі повинна становити 4-5\%.

Мета роботи - встановлення оптимальних параметрів режимів кондиціювання (зволоження) термічно мо- дифікованої деревини ясеня на основі експериментальних досліджень розподілу полів кінцевої вологості в середовищі перегрітої пари.

Методика дослідження. Експериментальні дослідження розподілу кінцевої вологості за товщиною термічно модифікованої деревини ясеня проводили на базі приватного підприємства "Long life wood" (м. Львів). Принципову технологічну схему i загальний вигляд термокамери зображено на рис. 1. Нагрівання термокамери здійснюється термомаслом з температурою кипіння $320{ }^{\circ} \mathrm{C}$, яке знаходиться у сорочках і нагрівальних колекторах у нижній частині камери (Militz, 2002). Нагрівання власне термомасла в колекторах відбувається за допомогою термоелектричних нагрівачів загальною потужністю 36 кВт. Для запобігання займанню деревини в процесі термічного модифікування на початку процесу в термокамері створюється вакуум (розрідження) глибиною 0,2-0,25 бар.

Надалі об'єм камери заповнюється парою, утвореної 3 видаленої з деревини вологи, а тиск у камері швидко піднімається до атмосферного і вище (Ala-Viikari \& Mayes, 2009). Далі тиск у термокамері підтримується на рівні 1,05-1,1 бара, а надлишок водяної пари через регулювальний клапан і охолоджувач збирається в ємкість

\section{Інформація про авторів:}

Андрашек Йосип Володимирович, канд. техн. наук, доцент, кафедра технологій захисту навколишнього середовища, деревини, безпеки життєдіяльності та соціальних комунікацій. Email: joseph.andrashek@nltu.edu.ua

Максимів Володимир Михайлович, д-р техн. наук, професор, кафедра технологій лісопиляння, столярних і дерев'яних будівельних виробів. Email: maksymiv@nltu.edu.ua

Петросюк Олександр Миколайович, менеджер. Email: o.petrosyuk@nltu.Iviv.ua

Цитування за ДСТУ: Андрашек Й. В., Максимів В. М., Петросюк О. М. Експериментальні дослідження кінцевої вологості термічно модифікованої деревини ясеня. Науковий вісник НЛтУ України. 2019, т. 29, № 2. С. 120-123.

Citation APA: Andrashek, J. V., Maksymiv, V. M., \& Petrosuik, O. M. (2019). Experimental studies of final moisture content of thermally modified ash wood. Scientific Bulletin of UNFU, 29(2), 120-123. https://doi.org/10.15421/40290224 
для конденсату. Технологічний процес складається 3 трьох фаз:

Фаза 1: підвищення температури в термокамері зі заданою швидкістю до $100{ }^{\circ} \mathrm{C}$. Надалі швидкість зростання температури зменшується і паралельно відбувається сушіння деревини до абсолютно сухого стану (реально до вологості 0,6-1,0 \%). Якщо в процесі підвищення температури різниця між температурою середовища в камері і температурою в центрі заготовки перевищує $20{ }^{\circ} \mathrm{C}$, то система автоматичного контролю і управління сповільнює підвищення температури з виконанням цього обмеження. Підвищення температури від 100 до $125{ }^{\circ} \mathrm{C}$ відбувається пропорційно зменшенню вологості деревини так, щоб за досягнення температури

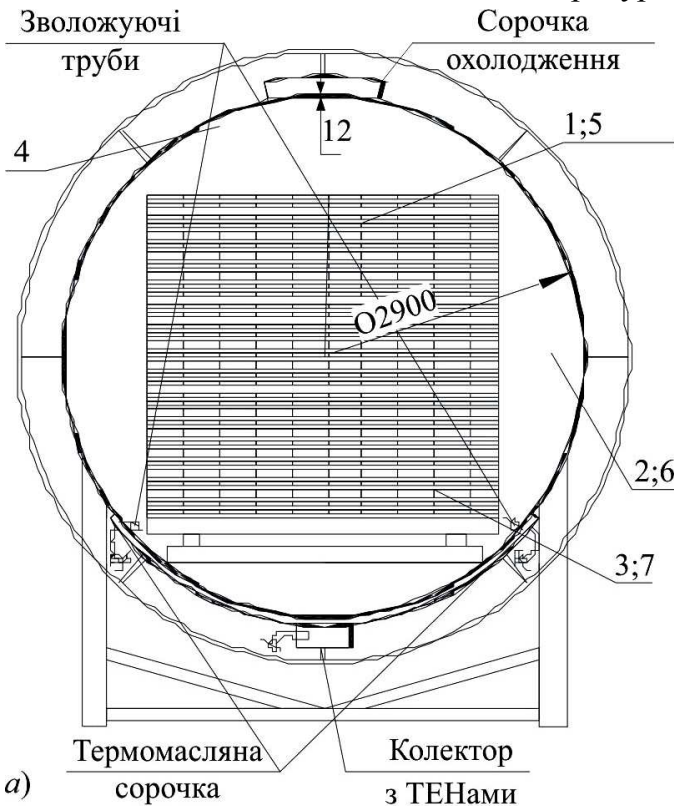

$125{ }^{\circ} \mathrm{C}$ вологість деревини досягла абсолютно сухого стану (реально 0,6-1,0 \%).

Фаза 2: зростання температури в термокамері зі заданою швидкістю до рівня температури термооброблення і витримка за заданої температури певний період. Рівень температури оброблення визначається переважно необхідним контрастом зміни кольору деревини, що обробляється. Тривалість витримки за температури термооброблення визначається часом, необхідним для досягнення різниці температур у $4{ }^{\circ} \mathrm{C}$ між датчиками в центрі зразка за товщиною і датчиками, розташованими біля пласті заготовок на глибині 2-3 мм. Час для досягнення такої різниці температур за температури термооброблення $195^{\circ} \mathrm{C}$ становить 5-6 год.

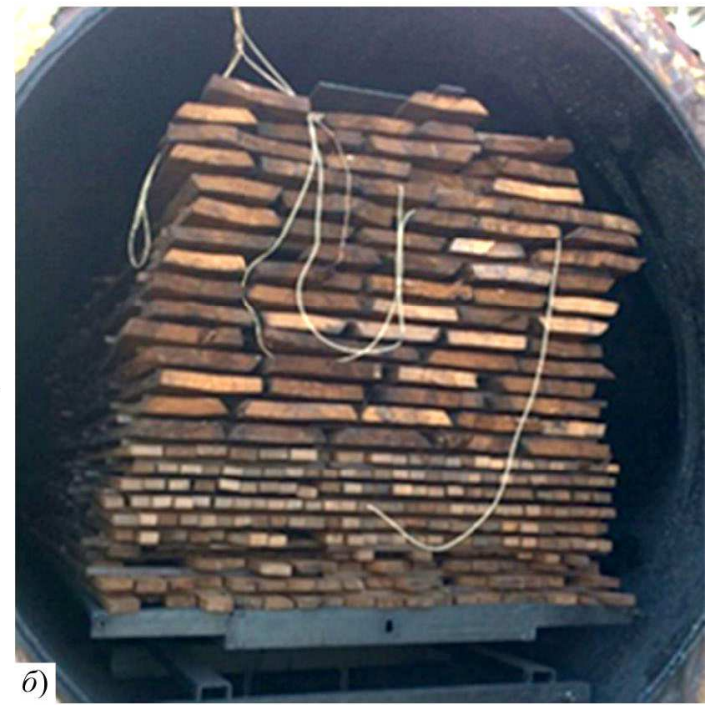

Рис. 1. Схема розташування температурних датчиків у термокамері: 1,5 - датчики температури в центрі зразка за товщиною і на глибині 2-3 мм від поверхні в передній і задній частинах камери (третій ряд заготовок зверху штабеля); 2,6 - температурний датчик середовища відповідно в задній і передній частинах камери; 3,7 - датчики температури в центрі зразка за товщиною і на глибині 2-3 мм від поверхні в передній і задній частинах камери (третій ряд заготовок знизу штабеля); 4 - температурний датчик середовища по середині довжини камери

Фаза 3: охолодження термокамери і кондиціювання (зволоження) термообробленої деревини. Охолодження термокамери здійснюється способом продуву повітря 3 навколишнього середовища через сорочку охолодження центробіжним вентилятором, який розташований 3 тильної сторони камери. У передній частині камери сорочка охолодження відкрита. За зниження температури до $150{ }^{\circ} \mathrm{C}$ в камері створюється розрідження 0,5-0,6 бар. Тоді вмикається електромагнітний клапан подачі конденсату у зволожуючі труби. Вода, що подається в камеру через зволожуючі труби (всмоктується вакуумом), миттєво випаровується, оскільки температура в термокамері значно вища від температури кипіння. За досягнення в камері атмосферного тиску (1 бар) подача води у зволожуючі труби зупиняється (відключається електромагнітний клапан). Надалі за досягнення розрідження в камері рівня 0,8 бар процес зволоження починається знову. Такий циклічний процес зволоження відбувається впродовж зменшення температури в термокамері до рівня $103{ }^{\circ} \mathrm{C}$. Тривалість циклу охолодженнязволоження у певних межах можна регулювати кількістю повітря, що подається в сорочку охолодження. Це здійснюється інвертором (частотним перетворювачем), через який підключений центробіжний вентилятор. За температури нижче $103{ }^{\circ} \mathrm{C}$ продовжується процес охо- лодження (без зволоження) до температури на $35-40{ }^{\circ} \mathrm{C}$ вище від температури навколишнього середовища.

Після закінчення процесу термооброблення і розвантаження камери відбирали 10 дощок для дослідження пошарової кінцевої вологості термічно модифікованої деревини ясеня товщиною 30 мм. На вибраних контрольних зразках відбирали секції для визначення пошарової і середньої вологості. У кожній дошці секції вологості відбирали у трьох місцях: по середині довжини дошки і на відстані 500 мм від двох торців. Схему відбору секцій вологості зображено на рис. 2.

Загальна кількість відібраних секцій становила 30 для визначення кінцевої середньої вологості дошок і 30 для визначення пошарової вологості. Секції пошарової вологості розколюють на пластинки за схемою, наведеною на рис. 2. Товщина пластинок становила 1,53 мм. Для визначення середньої і пошарової вологості використовували термогравіметричний аналізатор вологості фірми Radwag, загальний вигляд якого зображено на рис. 3 .

Прилад складається із камери сушіння і електронної ваги 3 точністю вимірювань 0,001 г. Підвід тепла до матеріалу відбувається безконтактним способом за допомогою інфрачервоної лампи. 

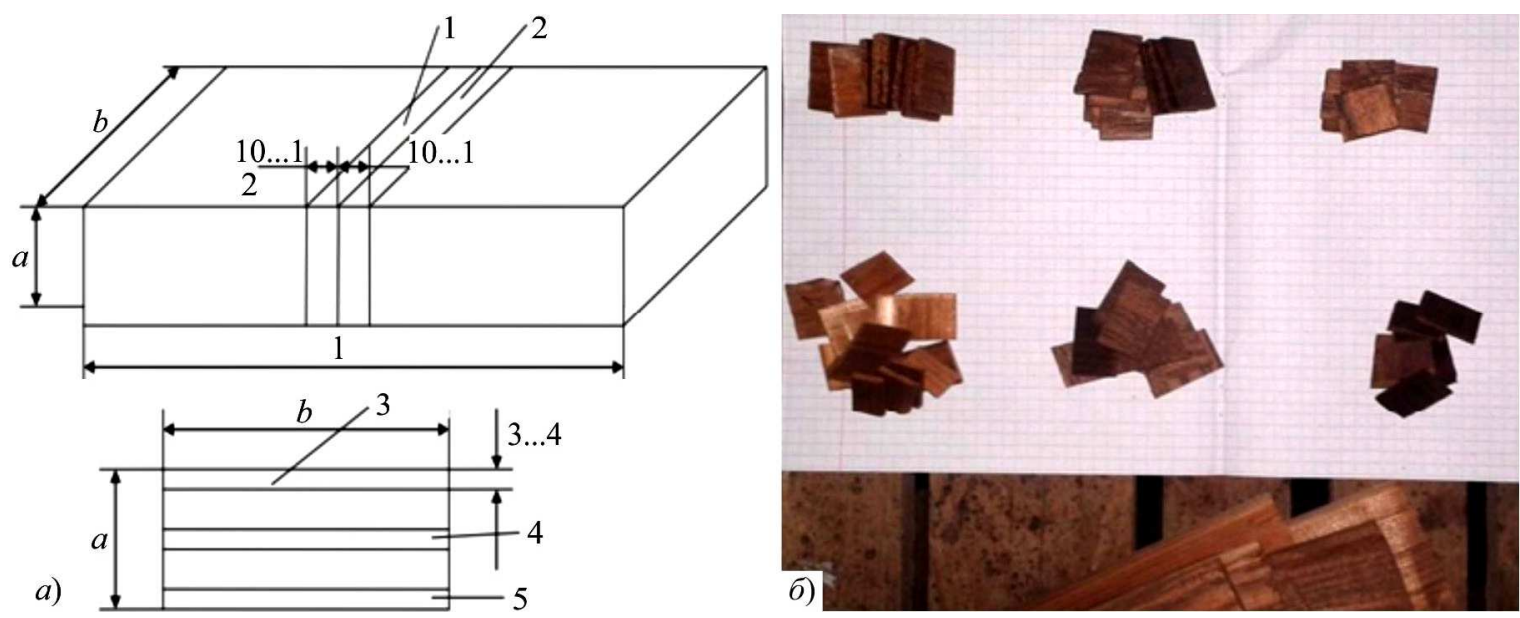

Рис. 2. Схема і фото випилювання секцій для визначення пошарової вологості заготовок: 1,2 - номери секцій вологості; $3,4,5$ номери пластинок для визначення пошарової вологості

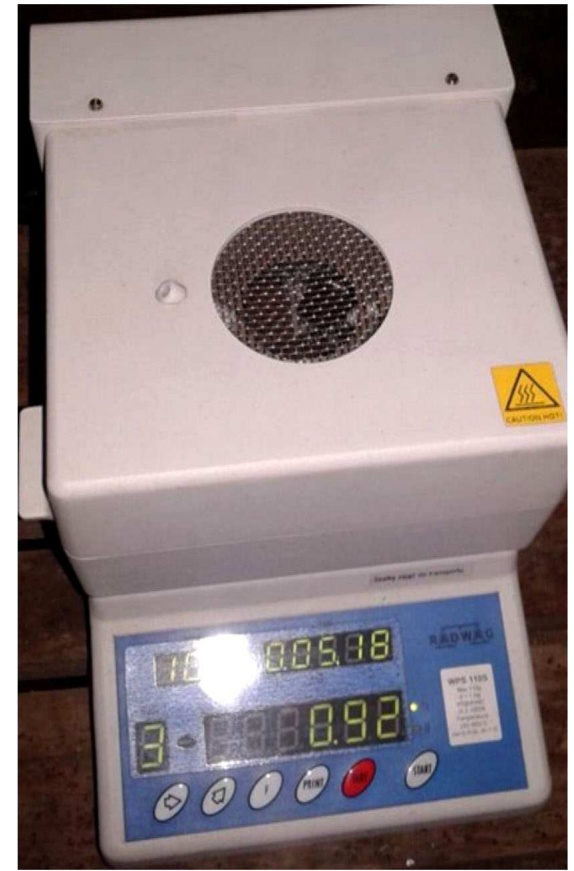

Рис. 3. Термогравіметричний аналізатор вологості фірми Radwag

Табл. 1. Результати вимірювань вологості третіх пластинок за товщиною термічно модифікованих заготовок ясеня товщиною 30 мм

\begin{tabular}{|c|c|c|c|c|c|c|c|c|c|c|}
\hline & 1 & 2 & 3 & 4 & 5 & 6 & 7 & 8 & 9 & 10 \\
\hline 1 & 0,6 & 0,56 & 0,67 & 0,63 & 0,61 & 0,62 & 0,61 & 0,61 & 0,6 & 0,62 \\
\hline 2 & 0,61 & 0,6 & 0,61 & 0,62 & 0,6 & 0,6 & 0,62 & 0,61 & 0,6 & 0,62 \\
\hline 3 & 0,61 & 0,63 & 0,65 & 0,61 & 0,58 & 0,62 & 0,61 & 0,62 & 0,63 & 0,6 \\
\hline
\end{tabular}

Час визначення вологості окремого зразка (секції чи пластинки) займає 10-15 хв і не потребує втручання 3 боку людини. Почергово випилюючи секції, визначали фактичну середню і пошарову кінцеву вологість термічно обробленої деревини ясеня. Результати записуємо в журнал спостережень, приклад розподілу кінцевої вологості третіх пластинок за товщиною термічно модифікованих заготовок ясеня товщиною 30 мм наведено в табл. 1.

Для вимірювання температури в середовищі термокамери використовували термопари, а для температури в деревині - термоперетворювач опору ТЭРА ТСП 1-7Pt100-B-3-60-4-3000-ТЭ- $(-50 \ldots .250){ }^{\circ} \mathrm{C}$ (рис. 4).

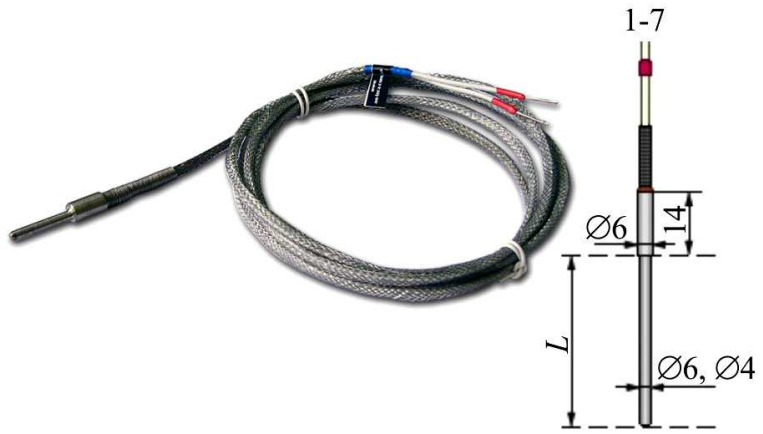

Рис. 4. Датчик температури - ТЭРА ТСП 1-7

Результати експериментального дослідження кінцевої вологості термічно модифікованої деревини ясеня. За результатами статистичного оброблення результатів спостережень (визначення дисперсії та середньоквадратичного відхилення; визначення інтервалу розсіювання; визначення коефіцієнта варіації; визначення середньоквадратичної похибки середнього значення; визначення показника точності досліду; визначення інтервалу довіри для математичного сподівання генеральної вибірки; визначення необхідної кількості дубльованих спостережень у кожному досліді основного експерименту) отримали підтвердження перевірки нормальності розподілу за критеріями асиметрії, ексцесу та за критерієм Пірсона. Результати експериментального дослідження наведено в табл. 2 і на рис. 5-7.

Табл. 2. Розподіл кінцевої вологості термічно модифікованої деревини ясеня за товщиною 30 мм у процесі охолодження

\begin{tabular}{|c|c|c|c|}
\hline \multirow{2}{*}{$\begin{array}{c}\text { Номер } \\
\text { плас- }\end{array}$} & Середньостатистичне значення вологості пластинки, \% \\
\cline { 3 - 4 } тинок & без зволо- & ження & зволоженням упродовж: \\
\hline & 1,39 & 3 год & 12 год \\
\hline 1 & 3,27 & 5,45 \\
\hline 2 & 0,97 & 2,58 & 4,15 \\
\hline 3 & 0,62 & 2,29 & 4,25 \\
\hline 4 & 0,83 & 2,35 & 4,75 \\
\hline 5 & 0,86 & 2,28 & 4,10 \\
\hline 6 & 0,69 & 2,37 & 4,87 \\
\hline 7 & 0,79 & 2,36 & 4,89 \\
\hline 8 & 0,80 & 2,31 & 4,15 \\
\hline 9 & 0,91 & 2,50 & 5,13 \\
\hline 10 & 0,58 & 2,83 & 5,25 \\
\hline 11 & 1,15 & 3,46 & 5,49 \\
\hline
\end{tabular}






Рис. 5. Розподіл кінцевої вологості термічно модифікованої деревини ясеня за товщиною 30 мм без зволоження у процесі охолодження

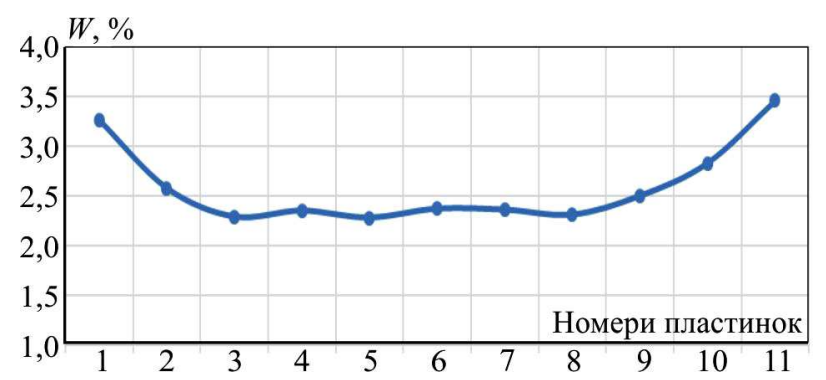

Рис. 6. Розподіл кінцевої вологості термічно модифікованої деревини ясеня за товщиною 30 мм зі зволоженням упродовж 8 год у процесі охолодження

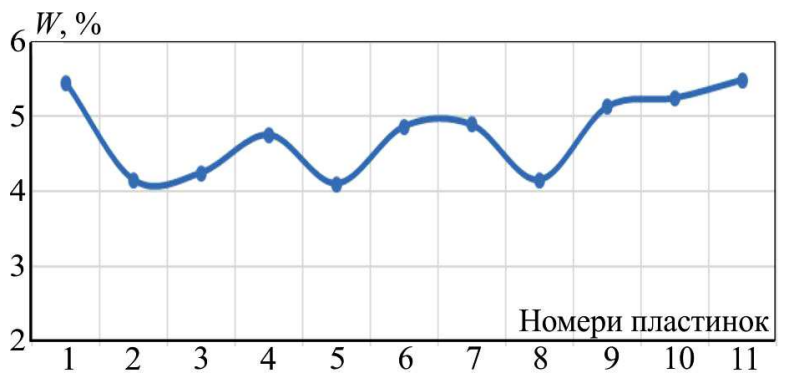

Рис. 7. Розподіл кінцевої вологості термічно модифікованої деревини ясеня за товщиною 30 мм зі зволоженням упродовж 12 год у процесі охолодження
Висновки. За результатами статистичної обробки експериментальних досліджень можна зробити такі висновки:

1. Розподіл кінцевої пошарової вологості за товщиною термічно модифікованої деревини ясеня без кондиціювання (зволоження) знаходиться на рівні 0,6-1,4 \%, що не допустимо, оскільки кінцева вологість повинна мати значення на рівні 4-5\% для виробів, що експлуатуються у зовнішньому середовищі (терасна дошка, садово-паркові вироби, блок-хаус та ін.).

2. Необхідний рівень кінцевої вологості за товщиною термічно модифікованої деревини ясеня товщиною 30 мм досягається способом кондиціювання (зволоження) тривалістю 12 год.

3. Для контролю рівня кінцевої вологості термокамеру доцільно обладнати кондуктометричними вологомірами.

4. Доцільно виконати теоретичні дослідження масообмінних процесів у процесі зволоження для розроблення раціональних режимів кондиціювання.

\section{Перелік використаних джерел}

Ala-Viikari, Ju., \& Mayes, D. (2009). New generation ThermoWo$\operatorname{od} \mathbb{R}$ - How to take Thermowood to the next level. (In: European Conference on Wood Modification 2009).

Andrashek, J., Maksymiv, V., Pfriem, A., Shchupakivskyy, R., Clauder, L., \& Kiyko, O. (2013). Statistical simulation of wood density changes due to thermal treatment. Invitation. XXI Symposium pokroky vo vyrobe a pouziti lepidiel $v$ drevopriemysle (adhesives in woodworking industry), (pp. 155-163), June 26-28. Zvolen, Slovakia.

Militz, H. (2002). Heat Treatment Technologies in Europe: Scientific Background and Technological State-of-Art. In: Proceedings of Conference on "Enhancing the durability of lumber and engineered wood products", February 11-13, Orlando. Forest Products Society, Madison, US.

Wahl, Antje. (2008). Wood market trends in Europe. Special publication SP-49, Vancouer.

\section{J. V. Andrashek ${ }^{1}$, V. M. Maksymiv $^{1}$, O. M. Petrosuik ${ }^{2}$ \\ ${ }^{1}$ Ukrainian National Forestry University, Lviv, Ukraine ${ }^{2} \mathrm{TzOV}$ "Aneruhomist", Velykyy Lyubin', Ukraine}

\section{EXPERIMENTAL STUDIES OF FINAL MOISTURE CONTENT OF THERMALLY MODIFIED ASH WOOD}

The research was conducted on the basis of Long Life Wood Private Enterprise in the thermal chamber of our own manufacture. According to the results of experimental studies, we have revealed that the final moisture content of thermally modified ash wood ranges from 0.6 to 1.4 percent without air conditioning, which is not permissible since the final moisture content should constitute from 4 to 5 percent. In order to solve the problem, we have proposed the modes of conditioning (humidification) as their introduction will increase the final moisture content of thermally modified ash wood to the required level and, consequently, will ensure the stability in the shape and size of products during exploitation. Using the phenomenon of dilution caused by a sharp decrease in temperature, moisturizing occurs due to the absorption of condensate formed in the initial phases of thermal treatment and accumulated in special containers, through special moisturizing pipes. Subsequently, the condensate supplied is instantly converted into vapor, since the temperature inside the thermal chamber is substantially higher than $100{ }^{\circ} \mathrm{C}$, and it creates a state of complete saturation of water vapor in the thermal chamber. According to the results of the research, we provide recommendations on the duration of conditioning of thermally modified ash wood depending on the temperature of the treatment and the thickness of the material.

Keywords: equilibrium moisture content; thermally modified wood; vacuum; thermally modified ash wood; thermogravimetric method; weight method. 